\title{
Epilithic and aerophilic diatoms in the artificial environment of Kungsträdgården metro station, Stockholm, Sweden
}

\author{
Lena Norbäck Ivarsson ${ }^{1 *}$, Magnus Ivarsson ${ }^{2}$, Johannes Lundberg ${ }^{3}$, Therese Sallstedt ${ }^{2,4}$, \\ and Catarina Rydin ${ }^{1}$ \\ Department of Ecology, Environment and Plant Sciences, Stockholm University, SE-106 91 Stockholm, Sweden \\ 2 Department of Palaeobiology and Nordic Center for Earth Evolution (NordCEE), Swedish Museum of Natural History, P.O. Box 50007, SE-104 05 \\ Stockholm, Sweden \\ ${ }^{3}$ Department of Botany, Swedish Museum of Natural History, Box 50007, SE-104 05 Stockholm, Sweden \\ ${ }^{4}$ Department of Biology, University of Southern Denmark, 5230 Odense M, Denmark
}

\begin{abstract}
The Kungsträdgården metro station is an artificial and urban subsurface environment illuminated with artificial light. Its ecosystem is almost completely unknown and as a first step to better understand the biology and rock wall habitats the diatom flora was investigated. A total of 12 species were found growing on the rock walls of Kungsträdgården metro station. The results show the diatom flora in Kungsträdgården to be dominated by e.g. Diadesmis contenta, Diadesmis perpusilla, Pinnularia appendiculata, Nitzschia amphibia, Nitzschia sinuata and Diploneis ovalis. One species, Caloneis cf. aerophila, has never been reported from Sweden before. Significant differences in the species composition between the sampling sites indicate Kungsträdgården metro station to be a heterogeneous habitat that provides different microhabitats.
\end{abstract}

Keywords: epilithic diatoms; lampenflora; metro station

Received 8 April 2013; Revised 5 September; Accepted 24 September 2013

Citation: Norbäck Ivarsson L., Ivarsson M., Lundberg J., Sallstedt T. and Rydin, C. 2013. Epilithic and aerophilic diatoms in the artificial environment of Kungsträdgården metro station, Stockholm, Sweden. International Journal of Speleology, 42 (3), 289-297. Tampa, FL (USA) ISSN 03926672 http://dx.doi.org/10.5038/1827-806X.42.3.12

\section{INTRODUCTION}

Urban underground facilities like utility tunnels (e.g. drainage, sewers, water, electrical power, gas, central heating) and tunnels for transportation is a crucial part of the urban infrastructure. Some urban subsurface areas, like metro systems, are constructed to daily hold and transport large quantities of people. An increased human presence in such systems urges the need to increase our understanding and knowledge of these environments. From an infrastructural or engineering point of view these environments are well known but other areas of the urban subsurface realm, like its biosphere, are still less known. This opens up a whole new niche for ecological research.

So far, there is a gap in our knowledge about the presence of diatoms in subsurface urban settings. In caves, on the other hand, diatoms have been studied at several locations (e.g. St. Clair and Rushforth, 1976; Garbacki et al., 1999; Lauriol et al., 2006; Poulíčková and Hašler, 2007; Mulec et al., 2008), typically in karst caves. Kashima et al. (1987), however, studied diatoms of the genus Melosira and their contribution in the production of coralloid speleothems in a cave developed in deposits of quaternary pyroclastic flows.

Caves are considered to be a difficult environment for autotrophic organisms to inhabit since they need light for the process of photosynthesis. Diatoms seem to be able to grow to a point where light conditions are about 54-127 lx (Abdullin, 2011), but the weak light affects both the morphology and physiology of diatom cells. Cell volume, chloroplast size and number of thylakoids increases with decreasing light intensities. Light quality affects the diatom cells; blue light seems to induce the highest rate of photosynthesis (Jørgensen, 1977). However, artificial light can also be utilized and the term Lampenflora is used collectively for all photosynthetic organisms that live in caves with artificial illumination (Roldán and Hernández-Mariné, 2009; Mulec, 2012). Diatoms as Lampenflora have been studied in show caves e.g. in Slovenia (Mulec et al., 2008), the Czech Republic (Pouličková and Hašler, 2007) and in Kentucky, USA (Smith and Olson, 2007) and in catacombs (Albertano, 1993, Albertano and Urzi, 1999, Llop et al., 2012). A characteristic of Lampenflora is that its species diversity is low compared to that of other habitats, e.g. cave entrances (Mulec, 2012). 
Here we report a study of diatoms, conducted in Kungsträdgården metro station, which is an environment illuminated with artificial light. It is the first study of diatoms in this type of urban environment. The aim of the study was to describe the aerophytic diatom community of Kungsträdgården metro station and increase the understanding of the wall habitats as well as how the diatoms dispersed into this system.

\section{Epilithic and aerophilic diatoms}

Diatoms are single-celled algae, which can be found in almost every aquatic habitat, often in high abundances and species richness (Julius and Theriot, 2010). Due to the presence of silica in their cell walls (the frustules), diatom morphology remains preserved during sedimentation and they are known from fossil assemblages from the Jurassic and onwards (Round et al., 1990). Their high abundances and often high species richness together with the fact that the species composition is very sensitive to factors in the environment, such as $\mathrm{pH}$, salinity, nutrient availability and temperature, make the diatoms excellent as paleoenvironmental indicators (Smol and Stoermer, 2010). Diatoms are also used for monitoring water quality and classifications thereof (Stevenson et al., 2010).

Diatoms are divided into planktonic taxa and benthic taxa, based on the ecological region in which they can be found. The ecology of benthic diatoms is less understood than that of planktonic diatoms (Round et al., 1990). Benthic diatom communities can be categorized by their preferred substrates, e.g. epipsammon (growing on sand grains), epiphyton (growing on submerged macrophytes or large microalgae), epizoon (growing on animals) or epilithon (growing on hard substrata, e.g. on rock) (Pouličková et al., 2008). Many classification systems of aerial habitats have been proposed (e.g. Kolbe, 1932; Petersen, 1935; Ettl and Gärtner, 1995). Patrick (1977) argues for the recognition of two groups: moist aerial habitats and dry aerial habitats.

An aerial habitat is a more stressful environment than an aquatic habitat (Patrick, 1977; Johansen, 2010). Johansen (2010) even describes these types of habitats as harsh and limiting in several respects. One important factor in aerial habitats is moisture availability and how desiccation resistant the taxa are. In a study from Subantarctica, Van de Vijver and Beyens (1999) show that species richness is closely related to the degree of moisture; dry habitats will contain fewer species than a wet habitat. Van de Vijver and Beyens (1997) further describe how the size of Pinnularia borealis Ehrenberg diminishes in dryer habitats. Temperature extremes are another important limiting factor in aerial habitats (Johansen, 2010), and water conductivity and $\mathrm{pH}$ affect diatom species composition (Fránková et al., 2009). Type of substrate influences the diversity of diatom communities. For example, plain rock faces or rock faces with mosses will be inhabited by different diatom flora. Additionally, many aerial diatoms only tolerate moderate levels of nitrogen (Johansen, 2010).

\section{AREA OF INVESTIGATION}

Kungsträdgården metro station is located in Norrmalm, Stockholm, Sweden (Fig. 1). The exits are situated about 150 meters from the Baltic Sea. The station opened in 1977 and is the end station for metro line 10 and 11 (Alfredsson et al., 2000). The station is built in granite, "Stockholm granite", which is about 1.8 Ga (Ivarsson and Johansson, 1995). Kungsträdgården is the deepest of all metro stations in Stockholm and is located 29.3 meters below sea level and approximately 34 meters below ground level (Alfredsson et al., 2000). Ulrik Samuelson, the artist who designed the station, aimed to create an "underground cave garden" (Alfredsson et al., 2000). This resulted in the walls of Kungsträdgården metro station not being covered with concrete, which is the case of most other subsurface metro stations in Stockholm. The station is illuminated with artificial light and there are local occurrences of seeping water on the walls. Associated with the seeping water secondary minerals, speleothems, are formed as flowstones, coralloids and stalactites. Kungsträdgården metro station houses a complete ecosystem with cyanobacteria, diatoms and mosses as primary producers (Ivarsson et al., 2013). The top predator in this ecosystem is the spider Lessertia dentichelis Simon, a species first reported from Sweden from this locality (Kronstedt, 1992).

\section{MATERIAL AND METHODS}

\section{Diatom preparation and analysis}

Three samples from Kungsträdgården metro station were collected on 5 November 2012 (Fig. 2). A spoon

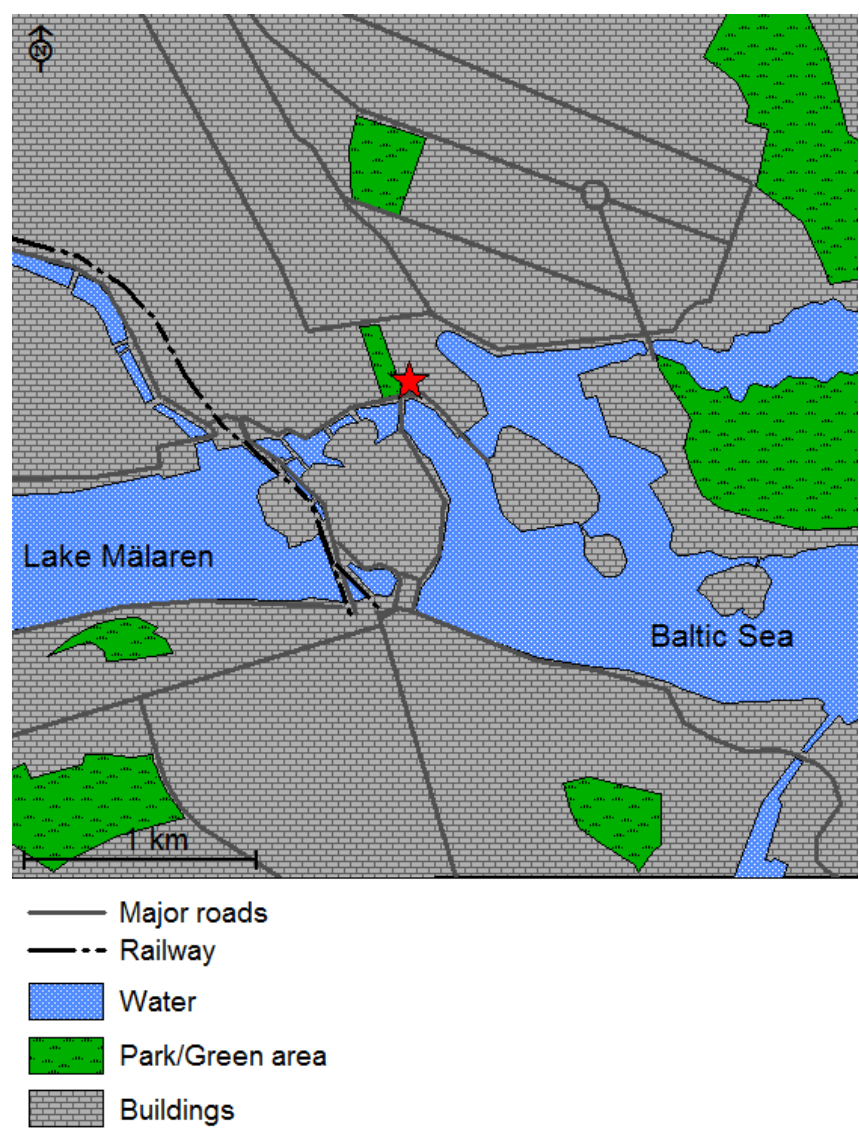

Fig. 1. Location of Kungsträdgården metro station in Stockholm. 

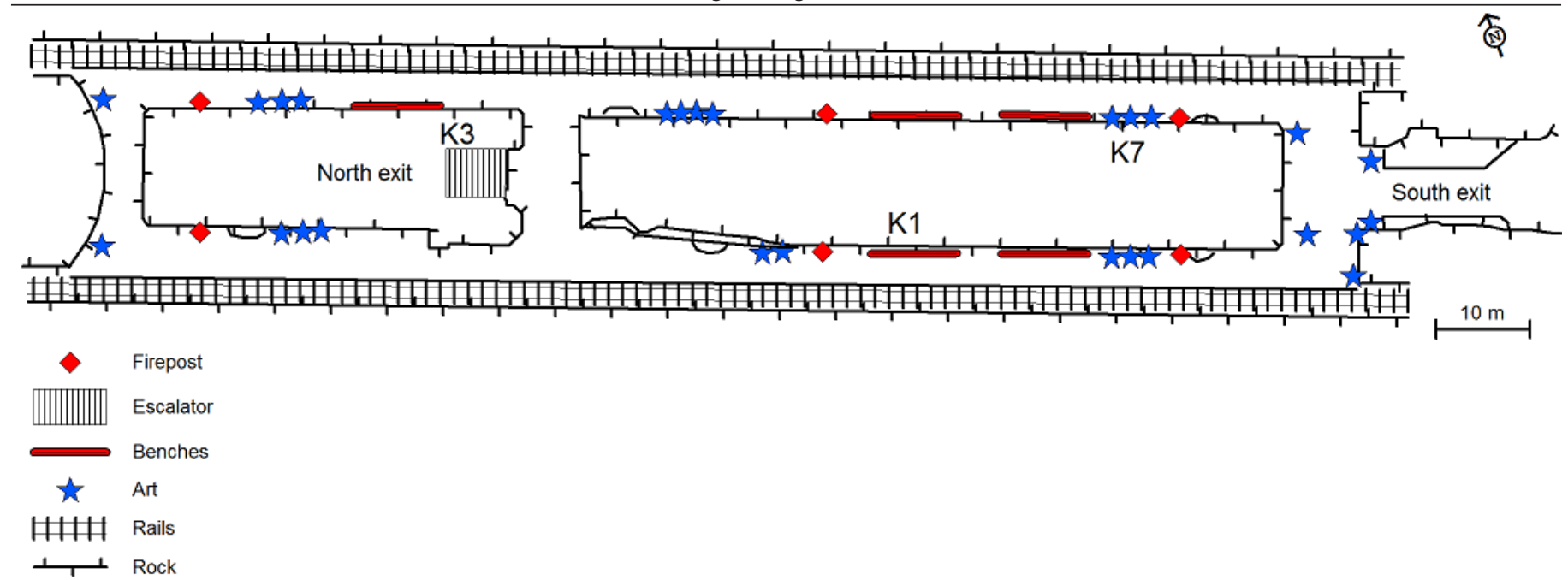

Fig. 2. Map of Kungsträdgården platform showing sampling sites K1, K3 and K7.

and a spatula were used to collect material from the walls of the platform. The sampling equipment was cleaned between each sampling site using water and paper tissues. For cleaning, samples were put in beakers and $25 \mathrm{ml}$ of $30 \%$ hydrogen peroxide $\left(\mathrm{H}_{2} \mathrm{O}_{2}\right.$; for the oxidation of organic matter $)$ and 25 $\mathrm{ml}$ of $10 \%$ hydrochloric acid $(\mathrm{HCl}$; to remove metal salts and carbonates) was added. The samples were then put on a hotplate where they were boiled for approximately two hours. When all the organic matter was oxidized, the samples were rinsed in distilled water six times and then, using a pasteur pipette, approximately $0.2 \mathrm{ml}$ of the cleaned samples were dropped onto glass coverslips. After 24 hours in room temperature the diatoms had settled and the water evaporated and the coverslips were mounted onto permanent microscope slides using Naphrax ${ }^{\mathrm{TM}}$.

The samples were studied using a Leitz orthoplan light microscope at $1000 \mathrm{x}$ using oil immersion. First investigations were conducted thoroughly, and along transects, with the aim to identify all diatoms to species level. After identification, counting was carried out along transects, according to the method described by Schrader and Gersonde (1978). At least 400 valves were counted in every sample. The diatom flora by Krammer and Lange-Bertalot (1986-1991) was routinely used for the identification of species, but other floras were also used, e.g. Cleve-Euler (1951), Hustedt (1930) and Patrick and Reimer (1966). For nomenclature issues the website Algaebase was consulted (Guiry and Guiry, 2013). Results from light microscopy studies were documented using an Olympus BX51 microscope and an Olympus DP71 camera. The images were cropped using the software cellSens Dimensions.

For Scanning Electron Microscopy (SEM), cleaned samples were air-dried on carbon tape, placed on stubs. The samples were coated with a thin layer of gold (20 seconds) using an Agar high resolution sputter coater. The SEM investigations were carried out using the microscope Oxford Instruments model 6853, and the software Pc-SEM. Both the light microscope images and the SEM images were used to aid species identification.

\section{ESEM analysis}

An XL30 environmental scanning electron microscope (ESEM) with a field emission gun (XL30 ESEM-FEG) was used to analyse the minerals and the diatom ooze. The ESEM was equipped with an Oxford $\mathrm{x}$-act energy dispersive spectrometer (EDS), backscatter electron detector (BSE) and a secondary electron detector (SE). The acceleration voltage was 20 or $15 \mathrm{kV}$ depending on the nature of the sample and the instrument was calibrated with a cobolt standard. Peak and element analyses were made using INCA Suite 4.11 software.

\section{RESULTS}

\section{The diatom flora in Kungsträdgården metro station}

Altogether 12 species are documented from Kungsträdgården metro station (Table 1). Relevant synonyms are mentioned in Table 1 and in the discussion; for more detailed nomenclatural information, see the webpage http://www.algaebase.org. All identified taxa are pennate diatoms and have at least one raphe. Size and morphology of reported diatoms conform to ranges and descriptions in Krammer and LangeBertalot (1986-1991), unless otherwise is stated below.

\section{Sample K1}

Sample K1 consisted of a "calcareous diatom ooze" (Fig. 3) that occur in depressions $(\sim 1-2 \mathrm{~cm})$ of coralloid speleothems. The composition of the speleothems were analysed by ESEM/EDS and consists of $\mathrm{CaCO}_{3}$ (calcite or aragonite) and the diatom ooze of a calcareous mix with traces of $\mathrm{Si}, \mathrm{Mg}$, and $\mathrm{S}$ (Table 2; Fig. 4). Eight species were identified in this sample. Diadesmis contenta (relative abundance, $\mathrm{ra}=44.2 \%$ ) (Fig. 5d), Pinnularia appendiculata ( $\mathrm{ra}=20.5 \%)$ (Fig. 5h), Nitzschia amphibia ( $\mathrm{ra}=19.8 \%)$ and Grunowia sinuata ( $\mathrm{ra}=12.7 \%$ ) (Fig. $5 \mathrm{j}$ ) were dominating in the sample. Species present at a lower abundance in this sample are Cymbella laevis ( $\mathrm{ra}=1.9 \%$ ) (Fig. $5 \mathrm{~g}$ ), Diadesmis perpusilla (ra=0.5\%) (Fig. 5e-f), Halamphora normanii (ra=0.2\%) (Fig. 5i) and Caloneis cf. aerophila (ra=0.2\%) (Fig. 5b). 
Table 1. Taxa found in Kungsträdgården and their relative abundance (\%).

\begin{tabular}{|c|c|c|c|c|}
\hline Taxon & Notes & K1 & K3 & K7 \\
\hline Caloneis cf aerophila Bock & & 0.2 & 1.5 & 11.4 \\
\hline Caloneis cf bacillum (Grunow) Cleve & & --- & --- & 0.5 \\
\hline Caloneis sp. & Specimens notably smaller than the normally reported size range & --- & 0.4 & 1.4 \\
\hline Cymbella laevis Nägeli & & 1.9 & --- & 3.6 \\
\hline Diadesmis contenta (Grunow ex Van Heurck) D.G. Mann & Synonym: Navicula contenta Grunow ex Van Heurck & 44.2 & --- & 37.7 \\
\hline Diadesmis perpusilla (Grunow) D.G. Mann & $\begin{array}{l}\text { Synonyms: Navicula perpusilla Grunow, Navicula gallica var. perpusilla (Grunow) } \\
\text { Lange-Bertalot, Diadesmis gallica var. perpusilla (Grunow) Lange-Bertalot }\end{array}$ & 0.5 & -- & --- \\
\hline Diploneis ovalis (Hilse) Cleve & & --- & --- & 8.9 \\
\hline Grunowia sinuata (Thwaites) Rabenhorst & & 12.7 & 86.6 & 2.2 \\
\hline Halamphora normanii (Rabenhorst) Levkov & Synonym: Amphora normanii Rabenhorst & 0.2 & 1.1 & --- \\
\hline Navicula sp. & & --- & -- & 0.2 \\
\hline Nitzschia amphibia Grunow & & 19.8 & 9.6 & 33.8 \\
\hline Pinnularia appendiculata (C. Arardh) Cleve & & 20.5 & 0.7 & 0.2 \\
\hline
\end{tabular}

\section{Sample K3}

Sample K3 did not consist of calcareous material, but of a dark brown diatom algae mat. Six species were identified. Grunowia sinuata dominated in the sample (ra=86.6\%) (Fig. 5j), together with Nitzschia amphibia (ra=9.6\%). Caloneis cf. aerophila ( $\mathrm{ra}=1.5 \%)$ (Fig. 5b), Halamphora normannii (ra=1.1\%) (Fig. 5i), Pinnularia appendiculata (ra=0.7\%) (Fig. 5h) were also documented from sample K3. Further, an unusually small and unidentified Caloneis species ( $\mathrm{ra}=0.4 \%$ )

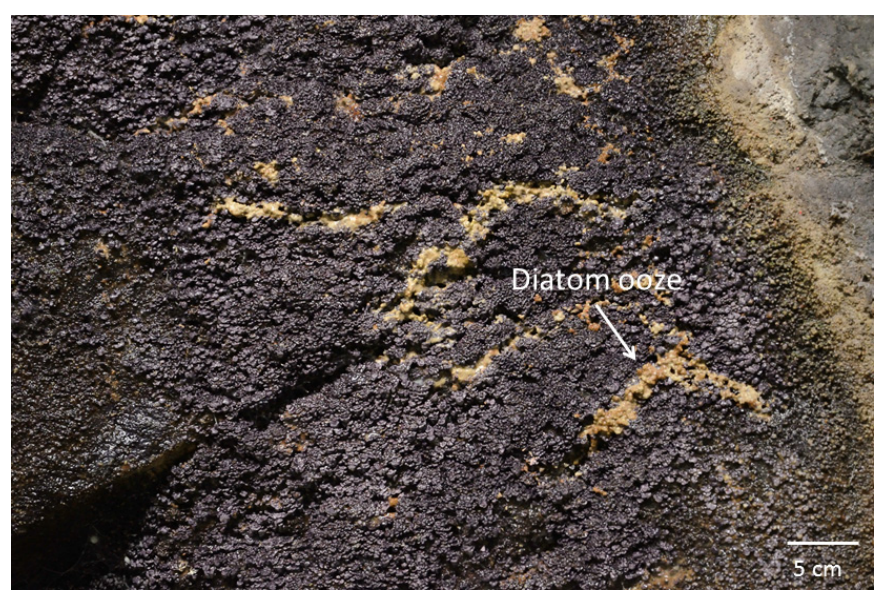

Fig. 3. Local occurrence of "calcareous diatom ooze" on coralloid speleothems found in Kungsträdgården metro station.

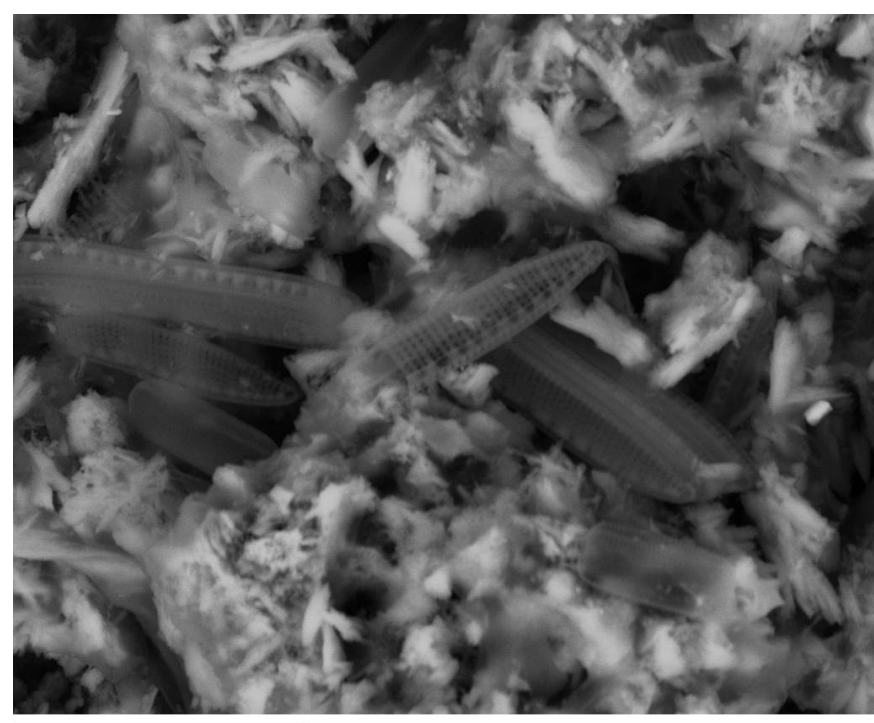

$20 \mu \mathrm{m}$

Fig. 4. ESEM image of the calcareous ooze.
(Fig. 5c) was found in this sample. It is approximately $5 \mu \mathrm{m}$ long and $2.5 \mu \mathrm{m}$ wide. Striae are 5 in $2 \mu \mathrm{m}$, which gives 25 in $10 \mu \mathrm{m}$.

\section{Sample $\mathrm{K7}$}

Like sample K1, sample K7 consisted of a "calcareous diatom ooze" (Fig. 3) that occur in depressions ( 1-2 cm) of coralloid speleothems. Ten species were identified in sample K7. Diadesmis contenta was dominating (ra=37.7\%) (Fig. 5d), together with Nitzschia amphibia (ra=33.8\%), Caloneis cf. aerophila (ra=11.4\%) (Fig. 5b) and Diploneis ovalis (ra=8.9\%) (Fig. 5k). Species found in less abundance in this sample were Cymbella laevis (ra=3.6\%) (Fig. 5g), Grunowia sinuata (ra=2.2\%) (Fig. $5 \mathrm{j})$, the small unidentified Caloneis species ( $\mathrm{ra}=1.4 \%$ ) (Fig. 5c), Caloneis cf. bacillum (ra=0.5\%) (Fig. 5a), Pinnularia appendiculata (ra=0.2\%) (Fig. 5h), and Navicula sp. (ra=0.2\%).

\section{DISCUSSION}

\section{The diatom flora of Kungsträdgården in comparison with other cave environments}

Cave entrances are known to be inhabited by a flora of cyanobacteria, algae (e.g. chlorophyta, chrysophyta and diatoms), mosses, ferns and angiosperms (Lundberg, 2011; Mulec, 2012). Algae mats often cover large parts of cave walls (Roldán and HernándezMariné, 2009). The moist cave environment, in which temperature typically is relatively stable, facilitates diatom growth (Palmer, 2007), and while decreasing light eventually will become a limiting growth factor in a cave, it is typically available in sufficient intensity near the cave entrance. The diatom species richness in Kungsträdgården was low compared to most cave inventories (e.g. St. Clair and Rushforth, 1976; St.

Table 2. EDS analysis of speleothems and the associated calcareous ooze.

\begin{tabular}{|l|l|l|l|l|}
\hline & CaCO3 & Ooze & Ooze & Ooze \\
\hline $\mathrm{C}$ & 11.40 & 14.73 & 16.90 & 12.80 \\
\hline $\mathrm{O}$ & 50.76 & 54.15 & 57.90 & 43.27 \\
\hline $\mathrm{Mg}$ & & 0.50 & & 0.58 \\
\hline $\mathrm{Si}$ & & 0.39 & 0.76 & 0.58 \\
\hline $\mathrm{S}$ & & 0.43 & & \\
\hline $\mathrm{Ca}$ & 37.85 & 29.80 & 24.44 & 42.77 \\
\hline Total & 100.00 & 100.00 & 100.00 & 100.00 \\
\hline
\end{tabular}



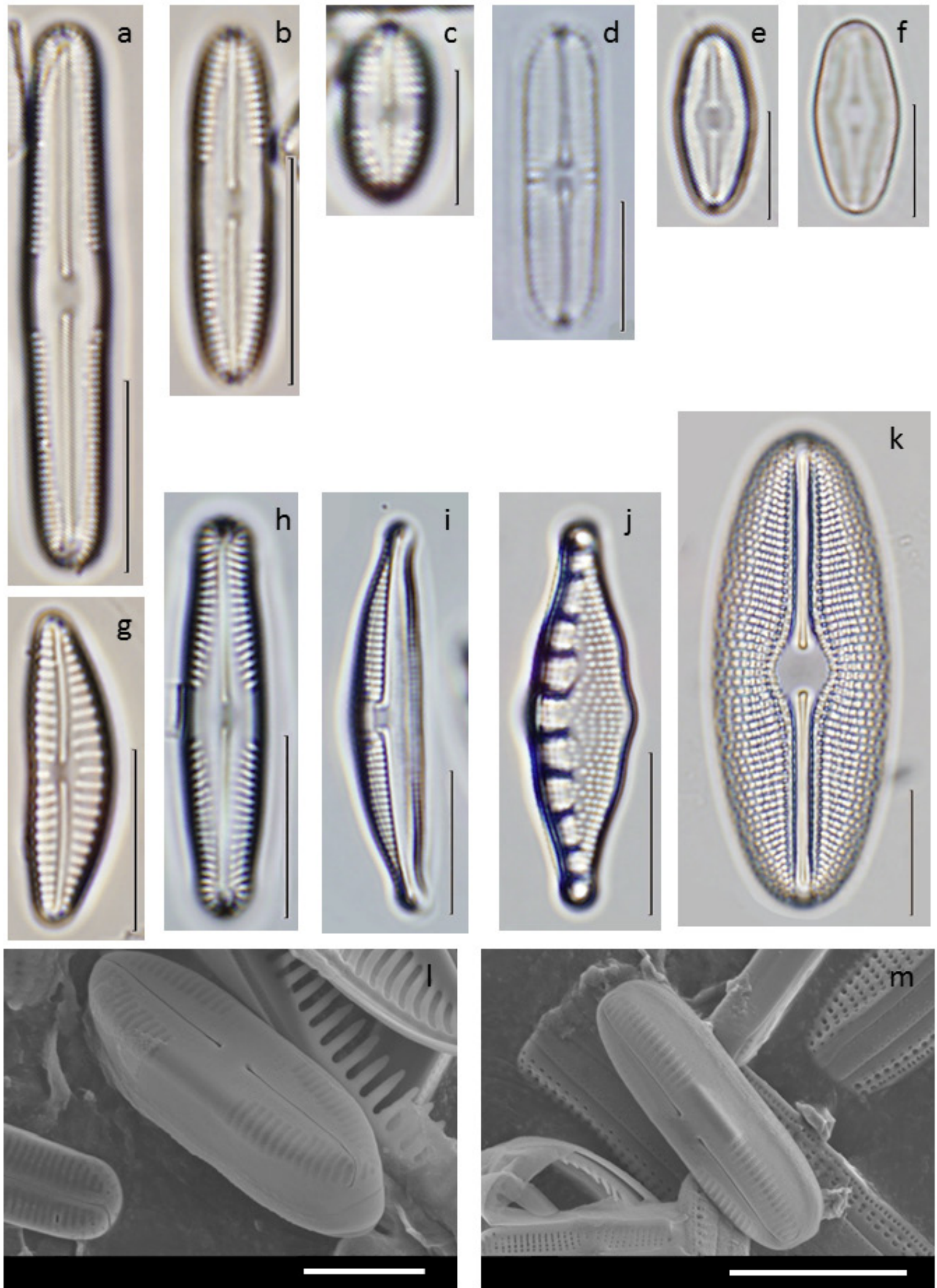

Fig. 5. Species found in Kungsträdgården samples. a) Caloneis cf. bacillum (scale bar $=10 \mu \mathrm{m}$ ); b) Caloneis cf. aerophila (scale bar $=10 \mu \mathrm{m}$ ); ) Caloneis species (scale bar $=5 \mu \mathrm{m}$ ); d) Diadesmis contenta (scale bar $=5 \mu \mathrm{m}$ ); e-f) Diadesmis perpusilla (scale bar $=5 \mu \mathrm{m}$ ); g) Cymbella laevis (scale bar $=10 \mu \mathrm{m})$; h) Pinnularia appendiculata (scale bar $=10 \mu \mathrm{m})$; i) Halamphora normanii (scale bar $=10 \mu \mathrm{m})$; j) Grunowia sinuata $(\mathrm{scale}$ bar $=$ $10 \mu \mathrm{m}$ ); k) Diploneis ovalis (scale bar $=10 \mu \mathrm{m}$ ); I-m) SEM images of Caloneis cf. aerophila (scale bar $=5 \mu \mathrm{m}$ in I and $10 \mu \mathrm{m}$ in $\mathrm{m}$ ). 
Clair et al., 1981; Poulíčková and Hašler, 2007). This finding fits the commonly observed pattern that species diversity of Lampenfloras is poor in comparison with cave entrances characterized by sun light (Mulec et al., 2008; Llop et al., 2012; Mulec, 2012). However, the Lampenflora in Kungsträdgården is represented by 12 diatom species, and this is a higher species richness than in most other studies of Lampenfloras (e.g. Poulíčková and Hašler, 2007; Smith and Olson, 2007; Mulec et al., 2008; Abdullin, 2011). Conceivably, this can be explained by the urban environment, from which the Kungsträdgården samples were taken. Compared to other cave environments, Kungsträdgården is more frequently visited by humans and that may contribute to dispersal. The metro station is further illuminated 24 hours a day which is distinctly more than a show cave that might be illuminated a few hours a day or a few days a week.

\section{Ecology of selected taxa}

Diadesmis perpusilla (Grunow) D.G. Mann. Synonyms: Navicula perpusilla Grunow, Navicula gallica var. perpusilla (Grunow) Lange-Bertalot, Diadesmis gallica var. perpusilla (Grunow) LangeBertalot. Fig. 5e-f.

Diadesmis perpusilla is only found in sample $\mathrm{K} 1$, and at a low relative abundance. According to Krammer and Lange-Bertalot (1986) it is often found on moist rocks, mosses and in soils. All species of Diadesmis are considered to be aerophilic (Spaulding and Edlund, 2009). Diadesmis perpusilla is characteristic of environments with considerable reduction in light intensity, for example in caves (Krammer and LangeBertalot, 1986). Species of the genus Diadesmis can also produce alternative frustules where the raphe slits are filled with silica. Due to this, these specimens can be confused with e.g. taxa of the fragilarioid genera (Round et al., 1990). Diadesmis perpusilla is reported from caves in e.g. Canada (Lauriol et al., 2006), United States (St. Clair and Rushforth, 1976; St. Clair et al., 1981), Belgium (Garbacki et al., 1999) and Slovenia (Mulec et al., 2008).

Diadesmis contenta (Grunow ex Van Heurck) D.G. Mann. Synonym: Navicula contenta Grunow ex Van Heurck. Fig. 5d.

Diadesmis contenta occurs in high abundance in the calcareous ooze samples (K1 and K7) of Kungsträdgården. This species is often found on rocks and mosses where water is seeping (Krammer and Lange-Bertalot, 1986). Diadesmis contenta is also one of few diatom species, which can live on dry rocks (Patrick, 1977). Like D. perpusilla, D. contenta is often found in environments with reduced light intensity (Krammer and Lange-Bertalot, 1986) and has previously been reported from caves in e.g. Canada (Lauriol et al., 2006), United States (St. Clair and Rushforth, 1976; St. Clair et al., 1981; Dayner and Johansen, 1991), Czech Republic (Pouličková and Hašler, 2007), Belgium (Garbacki et al., 1999), Slovenia (Mulec et al., 2008) and as Lampenflora in Kentucky, United States (Smith and Olson, 2007), Russia (Abdullin, 2011) and Malta (Llop et al., 2012).
Pinnularia appendiculata (C. Agardh) Cleve Fig. 5h.

Pinnularia appendiculata is present in all three samples, but is only abundant in sample K1 where it represents more than a fifth of the diatom community. It is an aerophilic species and can be found for example on wet mosses and rocks (Krammer and LangeBertalot, 1986). This species has been documented from a cave in Arizona, United States (Johansen et al., 1981).

\section{Diploneis ovalis (Hilse) Cleve Fig. 5k.}

Diploneis ovalis is only found in sample K7 where it comprises about $1 / 10$ of the diversity. It is a common epipelic diatom (Krammer and Lange-Bertalot, 1986), previously reported from a cave in Spain (Roldán et al., 2004).

\section{Cymbella laevis Nägeli Fig. 5g.}

Cymbella laevis is found in the calcareous samples (K1 and K7). The species is associated with oligotrophic calcareous waters, for example in karst landscapes, particularly on mosses and rocks (Krammer and Lange-Bertalot, 1986).

\section{Caloneis cf. aerophila Bock Fig. 5b.}

Caloneis aerophila is a rare species, associated with wet rocks (Krammer and Lange-Bertalot, 1986). Nevertheless, it makes up $11 \%$ of the taxa in sample $\mathrm{K} 7$, and is also found in the other samples. Species identification in this genus is problematic and we have only tentatively assigned certain diatoms to $C$. aerophila. Characters overlap between C. aerophila and C. bacillum, a problem that exists for several Caloneis species (Krammer and Lange-Bertalot, 1986). To our knowledge $C$. aerophila has not been reported from Sweden before, but it was not described until 1963 and it may have been identified as another species, for example C. bacillum, by early diatomologists.

\section{Caloneis sp. Fig. 5c}

The unusually small Caloneis specimens found in samples K7 and K3 could be small forms of C. aerophila or C. bacillum. If so, our findings would expand the known size range of these species (but see Kupe et al. 2010, who reported a small Caloneis species in a karst lake in Albania). Diatoms successively diminish in size as a natural consequence of vegetative reproduction and in cultivation, minute, round or misshaped valves are sometimes observed when cells fail to undergo the subsequent phase of auxspore formation (normally associated with sexual reproduction). However, such small or misshaped valves are rarely seen in natural diatom communities (Round et al., 1990), and the small specimens found here could instead represent a new, not yet described species of Caloneis. Both these scenarios are plausible, but a more expanded and detailed study (preferably with SEM) of this taxon is needed.

Halamphora normanii (Rabenhorst) Levkov. Synonym: Amphora normanii Rabenhorst. Fig. 5i.

Halamphora normanii is found in samples $\mathrm{K} 1$ and $\mathrm{K} 3$ at low relative abundances. This is an aerophilic 
species, mainly reported from wet mosses and on rocks where water is seeping (Krammer and LangeBertalot, 1986). The only previous report of this species in Sweden is from a paleolimnological study of small lakes, which were isolated from Lake Vänern during the Holocene (Risberg et al., 1996). It has also been reported from caves in Italy (Giordano et al., 2000).

\section{Microhabitat and distribution patterns in the metro station}

Dispersal of diatoms into Kungsträdgården metro station is most probably accomplished by air. Diatoms have been shown to be able to disperse over long distances by air (Spaulding et al., 2010), but are not known to migrate through micro-fractures in rock. The platform is not located under the Baltic Sea, which also contradict migration through cracks in the rock. It is also likely that the constant flow of people at the metro station might increase the chances and speed of introduction of new species to the station.

A spatial distribution of different communities of diatoms, characterized by different species composition, could be observed in Kungsträdgården metro station. This indicates a heterogeneous habitat providing different microhabitats, similar to some natural subterranean habitats (Culver and Pipan, 2009). Since no rapheless diatoms were found in any of the samples, motility seems to be important in the microhabitats of the calcareous ooze and the brown algae mat. However, there are no indications of an ability of the diatoms to move between the microhabitats on the wall; the distances between them are too great and the lack of coherent water seeping makes it impossible for the diatoms to migrate. Samples K1 and K7 are rather similar in their species composition, both dominated by Diadesmis contenta and Nitzschia amphibia. Both K1 and K7 are calcareous ooze samples and they have higher species richness than the brown algae mat of sample K3. This is in line with other studies of diatom species richness, which show a positive correlation with $\mathrm{pH}$, calcium and conductivity (Pouličková et al., 2004, Fránková et al, 2009). There are however differences between $\mathrm{K} 1$ and K7, such as Pinnularia appendiculata being abundant in $\mathrm{K} 1$ and the presence of Diploneis ovalis in $\mathrm{K} 7$ but not in $\mathrm{K} 1$.

None of the few species of diatoms known to be obligatory heterotrophs were found in this study. The diatoms in Kungsträdgården are primary producers, utilizing the artificial light from the illumination. They form, together with e.g. cyanobacteria and the moss Eucladium verticillatum (Brid.) Bruch \& Schimp, the primary foundation of the food web in the metro station.

\section{The speleothems-a result of biogenic speleogenesis?}

The formation of coralloid speleothems was studied in Togawa-Sakaidani-do Cave, Japan, by Kashima et al. (1987). This cave has developed in deposits of Quaternary pyroclastic flows and both the bedrock and the speleothems are rich in silica. Kashima et al. (1987) suggests that the growth of these speleothems is triggered by the activities of diatoms (Melosira spp.). Diatoms have also been shown to influence calcite precipitation in travertine crusts (Pentecost, 1998). This is done by depositing calcium carbonate crystals in the secreted mucilage (Pouličková and Hašler, 2007).

Nothing in the results of Kungsträdgården indicates that the diatoms trigger the growth of the speleothems found. However, the calcareous ooze (samples K1 and K7) are dominated by diatoms and it is likely that the diatoms are involved in the formation of this microhabitat. Diatoms are known to dissolve carbonates by excreting organic acids, thus, it is possible that they are actively involved in the persistence of the ooze (Brehm et al., 2005). Clearly, the calcareous ooze is a small and specialized niche in the ecosystem of the walls at Kungsträdgården metro station.

\section{CONCLUSIONS}

The Lampenflora of Kungsträdgården metro station is dominated by aerophilic taxa and is represented by 12 diatom species, a relatively high species richness compared to other studies of Lampenflora. All identified diatoms are autotrophic and pennate. Dispersal of diatoms into Kungsträdgården has probably occurred by air. It is likely that the diatoms are involved in the formation of the calcareous ooze found on the walls of Kungsträdgården metro station.

\section{ACKNOWLEDGEMENTS}

We thank Veneta Belivanova and Christian Pott (Department of Palaeobiology, Swedish Museum of Natural History) for invaluable help with SEM and light microscope images, respectively, Stefan Ohlsson (Department of Palaeobiology, Swedish Museum of Natural History) for laboratory assistance, Marianne Ahlbom (Department of Geological Sciences, Stockholm University), for assistance with ESEM analyses, Manuela Scheuerer (Ansaldo STS) for arranging the contacts with SL and for participating in the field work, and two anonymous reviewers for comments on the manuscript. Special thanks also to Gülsüm Kaya (AB Storstockholms Lokaltrafik, SL) for taking an interest in the project and approving clearance to the metro station for sampling.

\section{REFERENCES}

Abdullin S.R., 2011 - Effect of illumination on the distribution of phototrophic organisms in the entrance part of the Shul'gan-Tash Cave. Russian Journal of Ecology, 42: 249-251.

http://dx.doi.org/10.1134/S1067413611030039

Albertano P., 1993-Epilithicalgalcommunities in hypogean environments. Giornale botanico italiano 127: 386392. http://dx.doi.org/10.1080/11263509309431020

Albertano P. \& Urzì C., 1999 - Structural interactions among epilithic cyanobacteria and heterotrophic microorganisms in roman hypogea. Microbial Ecology 38: $244-252$.

http://dx.doi.org/10.1007/s002489900174

Alfredsson B., Berndt R. \& Harlén H., 2000 - Stockholm under: 50 år - 100 stationer. Bromberg, Stockholm, Sweden 227 pp. 
Brehm U., Gorbushina A. \& Mottershead D., 2005 - The role of microorganisms and biofilms in the breakdown of and dissolution of quartz and glass. Palaeogeography, Palaeoclimatology, Palaeoecology, 219: 117-129. http://dx.doi.org/10.1016/j.palaeo.2004.10.017

Cleve-Euler A., 1968 [1951] - Die Diatoméen von Schweden und Finnland. Cramer, Lehre, 958 pp.

Culver D. \& Pipan T., 2009 - The biology of caves and other subterranean habitats. UK University Press, Oxford, UK, $254 \mathrm{pp}$.

Dayner D.M. \& Johansen J.R., 1991 - Observations on the algal flora of Seneca Cavern, Seneca County, Ohio. The Ohio Journal of Science, 91: 118-121.

Ettl, H. \& Gärtner, G., 1995 - Syllabus der Boden - Luftund Flechtenalgen. Gustav Fischer Verlag, Stuttgart, Germany, $721 \mathrm{pp}$.

Fránková M., Bojková J., Pouličková A. \& Hájek M., 2009 - The structure and species richness of the diatom assamblages of the Western Carpathian spring fens along the gradient of mineral richness. Fottea, 9: 355-368.

Garbacki N., Ector L., Kostikov I. \& Hoffman L., 1999 Contribution à l'étude de la flore des grottes de Belgique. Belgian Journal of Botany, 132: 43-76.

Giordano M., Mobili F., Pezzoni V., Hein M.K. \& Davis J.S., 2000 - Photosynthesis in the caves of Frasassi (Italy). Phycologica, 39: 384-389. http://dx.doi.org/10.2216/i0031-8884-39-5-384.1

Guiry M. D. \& Guiry G. M., 2013 - Algaebase. Worldwide electronic publication, National University of Ireland, Galway. http://www.algaebase.org; searched on 11 June 2013.

Hustedt F., 1930 - Bacillariophyta (Diatomeae) In: Pascher A. (Ed.), die Susswasserflora von Mitteleuropas. Jena, Germany: Fischer: 466 pp.

Ivarsson C. \& Johansson Å., $1995-U-P b$ zircon dating of Stockholm granite at Frescati. Geologiska Föreningens Förhandlingar, 117: 67-68.

Ivarsson M., Lundberg J. E. K., Norbäck Ivarsson L., Sallstedt T., Scheuerer M. \& Wedin M., 2013 - Kungsträdgården, a granitic subway station in Stockholm: its ecosystem and speleothems. Proceedings of the 16th International Congress of Speleology, Brno, Ed. Filippi M. \& Bosák P. Volume 2, 217-220.

Johansen J.R., Rushforth S.R. \& Brotherson J.D., 1981 Subaerial algae of Navajo National Monument, Arizona. Great Basin Naturalist, 41: 433-439.

Johansen J.R., 2010 - Diatoms of aerial habitats. In: Smol J.P. \& Stoermer E.F. (Eds.) - The Diatoms: Applications for the Environmental and Earth Sciences. Cambridge University Press, Cambridge, UK: 287-308. http://dx.doi.org/10.1017/CBO9780511763175.025

Julius M.L. \& Theriot E.C., 2010 - The diatoms: a primer. In: Smol J.P. \& Stoermer E.F. (Eds.) - The Diatoms: Applications for the Environmental and Earth Sciences. Cambridge University Press, Cambridge, UK: 8-22. http:/ /dx.doi.org/10.1017/CBO9780511763175.003

Jørgensen E.G., 1977 - Photosynthesis. In: Werner, D. (Ed.) - The Biology of Diatoms. Oxford, UK: Blackwell: 150-168.

Kashima N., Irie T. \& Kinoshita N., 1987 - Diatom, contributors of coralloid speleothems, from TogawaSakaidani-Do cave in Miyazaki prefecture, central Kyushu, Japan. International Journal of Speleology 16: 95-100. http://dx.doi.org/10.5038/1827-806X.16.3.3

Kolbe R.W., 1932 - Grundlinien einer allgemeinen Ökologie der Diatomeen. Ergebnisse der Biologie, 8: 221-348. http://dx.doi.org/10.1007/978-3-642-91060-9_4

Krammer K. \& Lange-Bertalot H., 1986-Bacillariophyceae 1. In: Ettl H., Gerloff J., Heynig H., \& Mollenhauer D. (Eds.) - Süsswasserflora von Mitteleuropa 2/1. Stuttgart, New York: Gustav Fischer Verlag: 876 pp.
Krammer K. \& Lange-Bertalot H., 1988-Bacillariophyceae 2. In: Ettl H., Gerloff J., Heynig H., \& Mollenhauer D. (Eds.) - Süsswasserflora von Mitteleuropa 2/2. Stuttgart, New York: Gustav Fischer Verlag: 596 pp.

Krammer K. \& Lange-Bertalot H., 1991a Bacillariophyceae 3. In: Ettl H., Gerloff J., Heynig H., \& Mollenhauer D. (Eds.) - Süsswasserflora von Mitteleuropa 2/3. Stuttgart, New York: Gustav Fischer Verlag: $576 \mathrm{pp}$.

Krammer K. \& Lange-Bertalot H., 1991b Bacillariophyceae 4. In: Ettl H., Gerloff J., Heynig H., \& Mollenhauer D. (Eds.) - Süsswasserflora von Mitteleuropa 2/4. Stuttgart, New York: Gustav Fischer Verlag: $437 \mathrm{pp}$.

Kronstedt T., 1992 - Lessertia dentichelis: en för Sverige ny dvärgspindel $i$ Stockholms tunnelbana. Fauna och Flora, 87: 49-55.

Kupe L., Poçi A., Miho A. \& Hübener T. 2010 - Microscopic algae from karst lakes of Dumre region (Central Albania). Botanica Serbica, 34: 87-98.

Lauriol B., Prévost C. \& Lacelle D., 2006 - The distribution of diatom flora in ice caves of northern Yukon Territory, Canada: relationship to air circulation and freezing. International Journal of Speleology, 35: 83-92. http://dx.doi.org/10.5038/1827-806X.35.2.4

Llop E., Alvaro I., Hernández-Mariné M., Sammut S. \& Gómez-Bolea A., 2012 - Colonization of Maltese catacombs by phototrophic biofilms. How much does light matter? International Journal of Heritage in the Digital Era, 1: 289-294.

http://dx.doi.org/10.1260/2047-4970.1.0.289

Lundberg J., 2011 - Ljust liv i mörker - en förteckning över fynd av växter $i$ svenska grottor. Grottan, 46 (2): 10-31.

Mulec J., Kosi G. \& Vrhošek D., 2008 - Characterization of cave aerophytic algal communities and effects of irradiance levels in production of pigments. Journal of Cave and Karst Studies, 70: 3-12.

Mulec J., 2012 - Lampenflora. In: White W.B. \& Culver D.C. (Eds.) - Encyclopedia of Caves. Amsterdam: Academic Press: 451-456.

Palmer A. N., 2007 - Cave Geology. Cave books, Dayton, USA, 454 pp.

Patrick R. \& Reimer C.W. 1966 - The diatoms of the United States - exclusive of Alaska and Hawaii, Volume 1. The Academy of natural Sciences of Philaelphia, the Lingston Publishing Company, United States of America, $688 \mathrm{pp}$.

Patrick R., 1977 - Ecology of freshwater diatoms and diatom communities. In: Werner, D. (Ed.) - The biology of diatoms. Oxford: Blackwell: 284-332.

Pentecost A., 1998 - The significance of calcite (travertine) formation by algae in a moss-dominated travertine from Matlock Bath, England. Archiv für Hydrobiologie, 143: 487-509.

Petersen J.B., 1935 - Studies on the biology and taxonomy of soil algae. Dansk Botanisk Arkiv, 8: 1-180.

Pouličková A., Hájková P., Křenková P. \& Hájek M., 2004 Distribution of diatoms and bryophytes on linear transects through spring fens. Nova Hedwigia, 78: 411-424. http://dx.doi.org/10.1127/0029-5035/2004/0078-0411

Poulíčková A. \& Hašler P., 2007 - Aerophytic diatoms from caves in central Morovia (Czech Republic). Preslia, 79: 185-204.

Poulíčková A., Hašler P., Lysáková, M. \& Spears, B., 2008 - The ecology of freshwater epipelic algae: an update. Phycologia, 47: 437-450.

http://dx.doi.org/10.2216/07-59.1

Risberg J., Sandgren P. \& Andrén E., 1996 - Early Holocene shore displacement and evidence of irregular isostatic uplift northwest of Lake Vänern, western Sweden. Journal of Paleolimnology, 15: 47-63. http://dx.doi.org/10.1007/BF00176989 
Roldán, M., Clavero, E., Canals T., Gómez-Bolea A., Ariño X. \& Hernández-Mariné M., 2004 - Distribution of phototrophic biofilms in cavities (Garraf, Spain). Nova Hedwigia, 78: 329-351. http:/ /dx.doi.org/10.1127/0029-5035/2004/0078-0329

Roldán M. \& Hernández-Mariné M., 2009 - Exploring the secrets of the three-dimensional architecture of phototrophic biofilms in caves. International Journal of Speleology, 38: 41-53.

http://dx.doi.org/10.5038/1827-806X.38.1.5

Round F.E., Crawford R.M. \& Mann D.G., 1990 - The diatoms - biology and morphology of the genera. Cambridge University Press, Cambridge, UK, 723 pp.

Schrader H.-J. \& Gersonde R., 1978 - Diatoms and silico-flagellates. In: Zachariasse W.J., Riedel W.R., Sanfilippo A., Schmidt R.R., Brolsma M.J., Schrader, H.J. Gersonde R., Drooger M.M. \& Broekman J.A. (Eds.) - Utrecht micropaleontological bulletins 17, micropaleontological counting methods and techniques. Hoogeveen, The Netherlands: Loonzetterij Abe: : 127-176.

Smith T. \& Olson R., 2007 - A taxonomic survey of Lamp flora (algae and cyanobacteria) in electrically lit passages within Mammoth Cave National Park, Kentucky. International Journal of Speleology, 36: 105-114. http://dx.doi.org/10.5038/1827-806X.36.2.6

Smol J.P. \& Stoermer E.F., 2010 - Applications and uses of diatoms: prologue. In: Smol J.P. and Stoermer E.F. (Eds.) - The diatoms: applications for the environmental and earth sciences. Cambridge, UK: Cambridge University Press: 3-7.

http:/ / dx.doi.org/10.1017/CBO9780511763175.002

Spaulding S. \& Edlund M., 2009 - Diadesmis. In: Diatoms of the United States. Retrieved December 11, 2012, from http:// westerndiatoms.colorado.edu/taxa/genus/Diadesmis
Spaulding S.A., Van de Vijver B., Hodgson D.A., McKnight, D.M., Verleyen E. \& Stanish L., 2010 Diatoms as indicators of environmental change in Antarctic and subantarctic freshwater. In: Smol J.P. $\&$ Stoermer E.F. (Eds.) - The diatoms: applications for the environmental and earth sciences. Cambridge, UK: Cambridge University Press: 267-283. http://dx.doi.org/10.1017/CBO9780511763175.015

St. Clair L.L. \& Rushforth S.R., 1976 - The diatoms of Timpanogos Cave National Monument, Utah. American Journal of Botany, 63: 49-59.

http://dx.doi.org/10.2307/2441667

St. Clair L.L., Rushforth S.R. \& Allen J.V., 1981 - Diatoms of Oregon Caves National Monument, Oregon. Western North American Naturalist, 41: 317-332.

Stevenson R.J., Pan Y. \& Van Dam H., 2010 - Assessing environmental conditions in rivers and streams with diatoms. In: Smol J.P. and Stoermer E.F. (Eds.) - The diatoms: applications for the environmental and earth sciences. Cambridge, UK: Cambridge University Press: 57-85. http://dx.doi.org/10.1017/CBO9780511763175.005

Van de Vijver B. \& Beyens L., 1997 - The epiphytic diatom flora of mosses from Stromness Bay area, South Georgia. Polar Biology, 17: 492-501.

http://dx.doi.org/10.1007/s003000050148

Van de Vijver B. \& Beyens L., 1999 - Moss diatom communities from Ile de la Possession (Crozet, Subantarctica) and their relationship with moisture. Polar Biology, 22: 219-231. http://dx.doi.org/10.1007/s003000050414 